\title{
板ガラスの音響透過損失に関する研究 STUDY ON SOUND TRANSMISSION LOSS OF GLASS PANE
}

\author{
吉 村 純 一* \\ Junichi YOSHIMURA
}

\begin{abstract}
In measuring the sound transmission loss of glass panes, there are many important factors such as the size of specimen, the test opening and installing conditions. Therefore, many researches were performed in order to examine the influence of the factors. In order to measure the test specimen in the standardized conditions, additional test requirements for installation of glass panes is included in ISO standard 140-1 and 3 (ISO method). However, it differs from the conventional Flat Glass Association method (FGA method), in which the sound transmission loss has been measured by following the actual Japanese window installation. Therefore, it is important to make clear the difference between the two methods, because we have already accumulated performance data of many kinds of glass panes and also clarified the influence of the niche (niche effects) by applying FGA method.
\end{abstract}

Keywords : sound transmission loss, glass pane, double glazing, laminated glass

音響透過損失、板ガラス、複層ガラス、合わせガラス

\section{1、まえがき}

建築材料の音響透過損失の測定結果は、その面密度や剛性などの 物理特性だけでなく、試料の大きさ、取り付け開口、支持方法など の様々な影響を受ける。また、実際の使用状況の制約から試料寸法 が小さくなる場合は、試料端の拘束条件や音場の局所的な変動が、 結果により鋭敏に反映される。板ガラスは、均質で一様な厚さの材 料であるにもかかわらず、公表される音響透過損失の測定結果は必 ずしもよく一致するものではなく、それらの差異は、複層ガラスや 合わせガラスなどのような試料自身の特性とそれらが試験された実 験室の特性の両方に依存しているものと考えられる。

個別の試験条件による測定結果の差異を少なくするために、ISO 140 「建築物及び建築部材の遮音測定」Part 1 「実験室条件」および

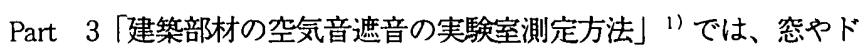
ア等と共にガラス単体についての測定方法を詳細に規定している。 この様な統一した試験方法に基づいた測定結果は、ガラスの透過損 失の標準計測値として利用されるべきであるが、一方において、実 際の取付け条件における性能向上を目指して、個別の条件に基づく 検討も進める必要がある。それには、遮音性能を左右する要因を把 握しておくことが重要であり、その条件が試料の実際の使用状況に おいても得られるものであるか、或いは実験室固有の試験条件であ るかといった見極めも必要となる。

本研究では、試料の取り付け開口の影響についての幾つかの検討
結果に基づき、測定結果に与える試料周辺の状況や音場の影響を把 握し、さらに各種板ガラスの音響透過損失の特質や差異について比 較検討した。

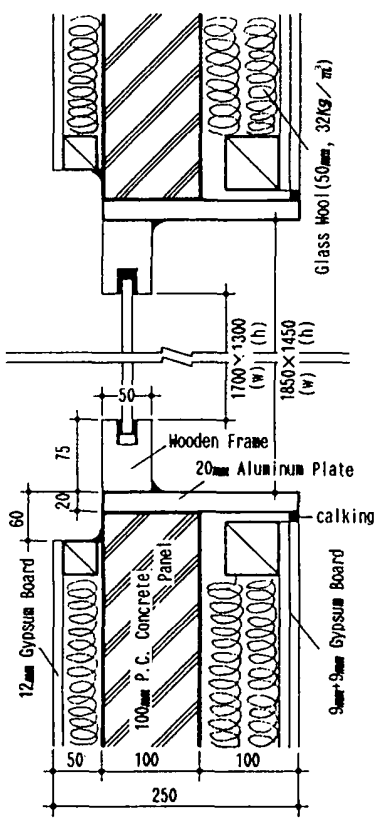

(a) FGA method

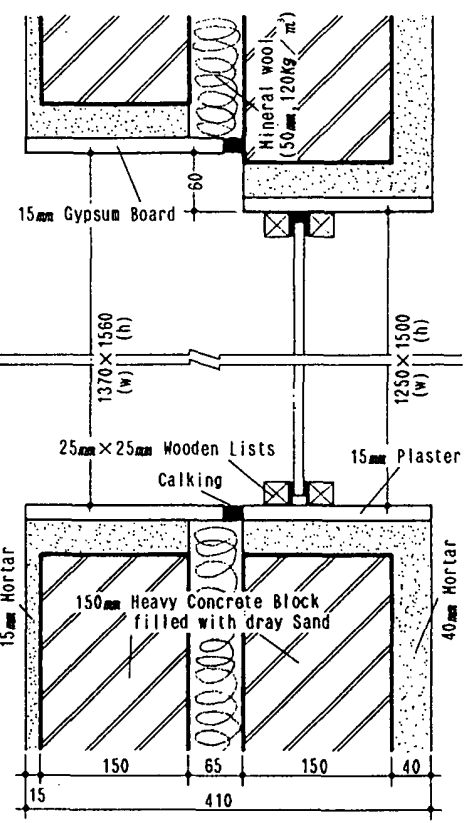

(b) ISO method
Fig.1 Vertical sections of the test openings and installations. 
2. 板ガラスの音整透過損失測定結果の不一致の要因

2. 1 試衼取り付け開口の影榔

測定試料の取り付け開口の影響を検討すために、2㣫頑の試験開 口調整壁（試料の大きさに合わせて開口部の大きさを調整するため に設ける壁）を用いた。図-1は、本所第三残智室と第四残響室（共 に不整形 7 面体、容積 $164 \mathrm{~m}^{3} 、$ 表面積 $179 \mathrm{~m}^{2} 、$ 拡散板無し、開口部寸 法 $3.0 \mathrm{~m} \times 3.0 \mathrm{~m} ）$ の間に構築された開口部調䇥壁の断面を示したも のである。(a)の調整壁は、日本の標準的な家屋の開口を模したもの で、試料 $(1700 \mathrm{~W} \times 1300 \mathrm{H})$ は材杂にパテで取り付けられ、開口内 のサッシの設置相当位置に固定した（以下FGA方式と称す）。また、 (b)はISO 140-1,3に規定されるガラス測定用の開口で、試料面積が小 さく $(1250 \mathrm{~W} \times 1500 \mathrm{H})$ 壁が厚いため、開口の凹み（ニッシェ）が (a)に比べて深くなっている（以下ISO方式と称す）。なおこのISOの 規定では、試料の設置位置（ニッシェの比が2:1）や取り付け部材ば かりでなく、使用するパテの品種に至るまでの詳細な測定条件が定 められている。FGA方式での測定は、JS A 1416 「実験室における 音菿透過損失湘定方法」に、ISO方式はISO 140-1，3"1 に基ついて実 施した。両方式とも同じ実験室の同じ開口を用い、室内音圧レベル は各室5力所の固定測定点で観測した。前者の值は手順に基づく 1 カ 所の音源位置での測定結果で、後者は図-6に例示した 6 所の音源 位置での結果を算術平均した值である。また前者は $1 / 3$ オクターブ 带域ノイズを用い各帯域ごとに測定し、後者は規定に基づくスペク トル調整をした広帯域ノイズを用いて総ての帯域を同時に測定した。

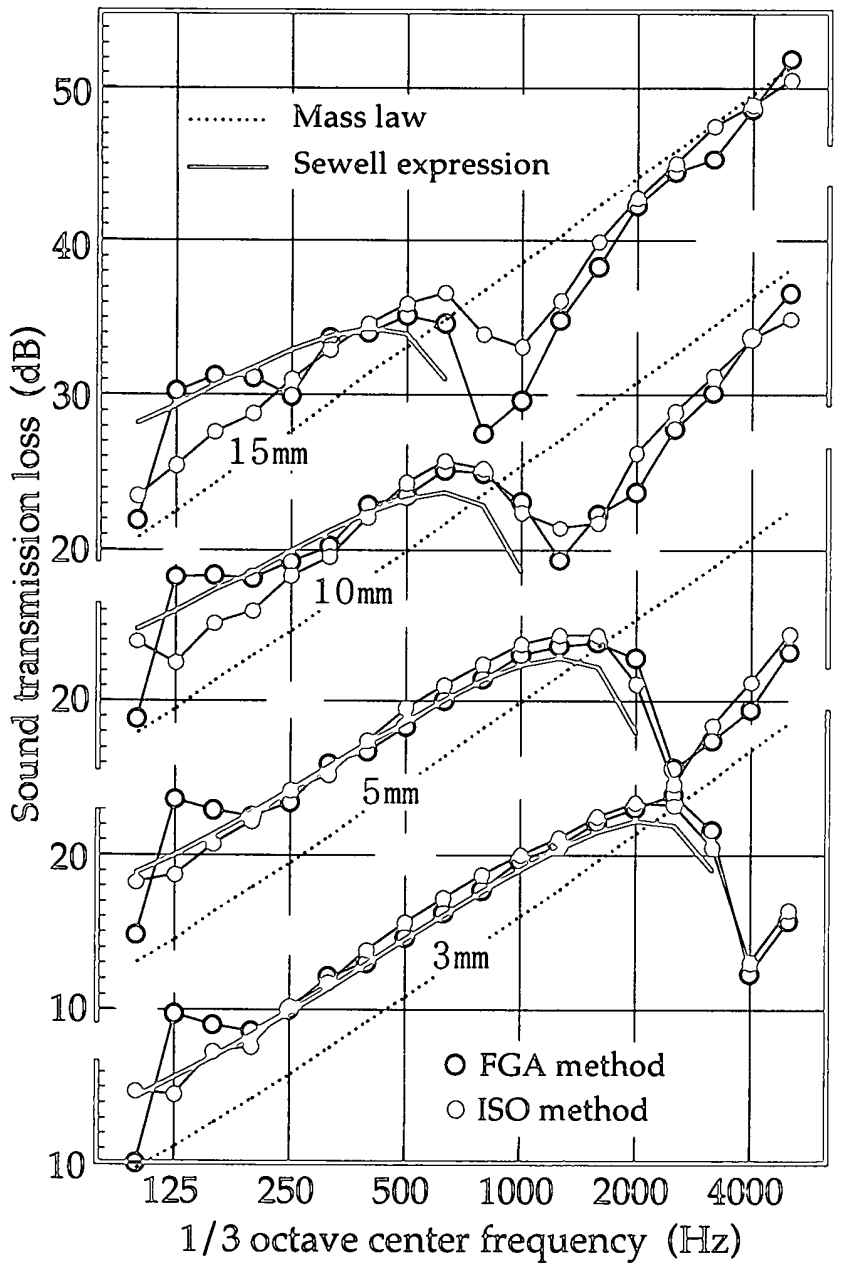

均質で一様な単板ガラスについての両方式による測定結果を比較 して図-2に示す。薄いガラスの両者の対応は比較的よいが、ガラス が厚くなるにつれコインシデンス周波数 $f_{C}$ 付近での落ち込みが大き く異なったものとなっている。ISO方式による結果の落ち込みが浅 くなるのは、コインシデンス限界周波数に近い周波数領域での壁に 近い音の入射条件とニッシェの媣さが関係するため、 $f_{C}$ が低い周波 数、即ち波長が長くなる厚いガラスほどその差がより顕著に現れた ものと考えられる。即ち、 $f_{C}$ が高い周波效領域に生じる薄い板ガラ スでは、凹みの側面での反射で、画者は同等な入射条件が得られる が、ガラスか厚くなるほど $f_{C}$ が低い周波放に移行し、凹みの側面の 大きさが波長に比べて相対的に小さくなるため、壁に沿った音の入 射が滅少し、結果的に落ち込みが浅くなったものと解釈される。ま た、ごく低い周波数領域では、ISO方式の測定結果が傾向的に低い 值となっている。これについてもニッシェの形状が両者で異なるた めと考えられるが、A Copsが指摘した、より深いニッシェはより低 い透過損失を与える ${ }^{2)}$ という傾向に合致している。

なお、測定された透過損失は $f_{C}$ 以下の周波数带域において、(1) 式のランダム入射の質量則による計算值より多少大きな値となって いる。

$$
\begin{aligned}
T L_{0} & =10 \log _{10}(m \cdot f)-43 \\
T L & =T L_{0}-10 \log _{10}\left(0.23 \cdot T L_{0}\right)
\end{aligned}
$$

ここに、 $m$ は面密度 $\left(\mathrm{kg} / \mathrm{m}^{2}\right) 、 f$ は周波数 $(\mathrm{Hz})$ である。

図中に示したSewellの質量則 ${ }^{3)}$ は、 $f_{C}$ 以下の周波数帯域の実測值 とよく一致している。板ガラスのような狭い面積で測定される試料

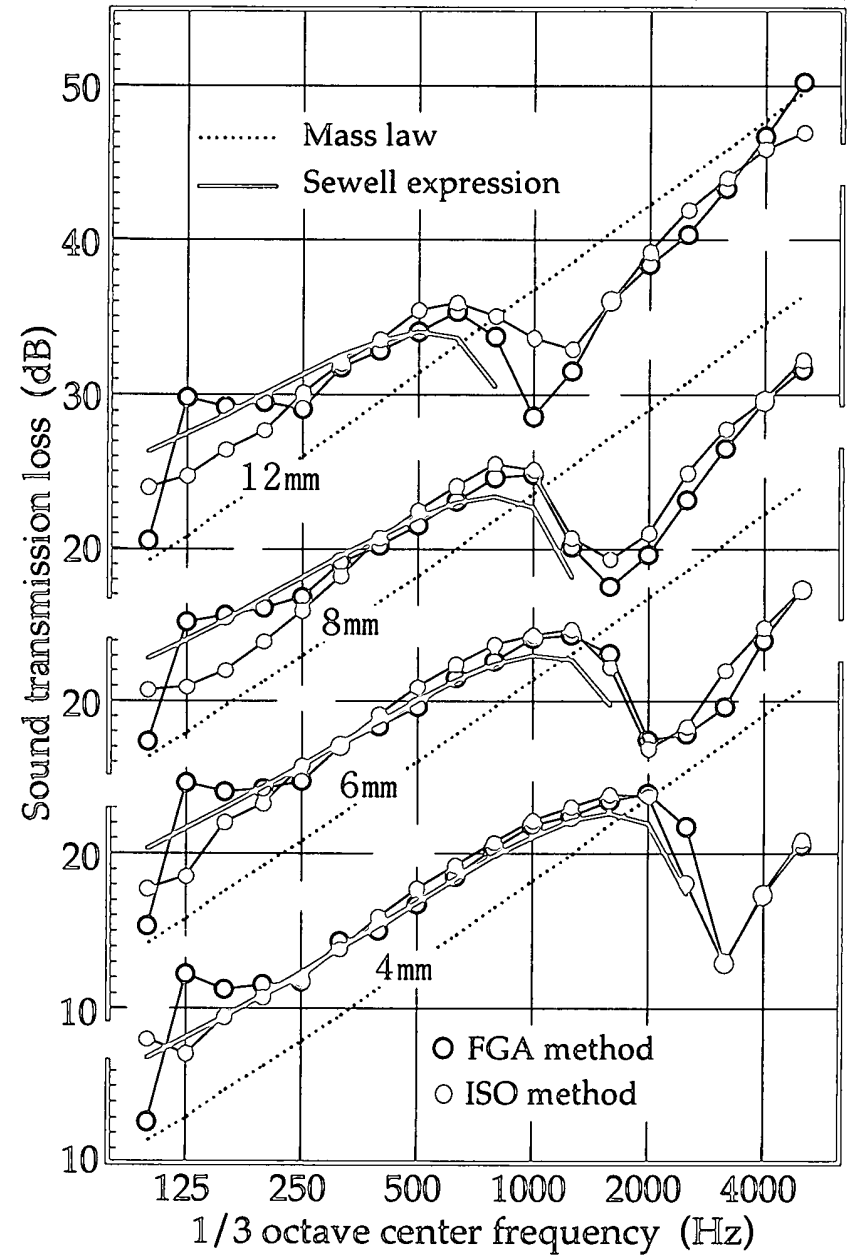

Fig.2 Comparison of sound transmission loss data measured by FGA method and ISO method for several kinds of single glazing. 
の音響透過損失の予測では、有限の大きさの板の共振現象を考慮す る必要があり、(2式による值は実測值とよく一致した傾句を示した。

$T L=T L_{0}-10 \log _{10}\left\{\ln \left(k A^{1 / 2}\right)\right\}+20 \log _{10}\left\{1-\left(f / f_{C}\right)^{2}\right\}$

$$
f_{C}=12100 / t
$$

ここに、 $k$ は波長定数 $(2 \pi f / c 、 c$ は音速) 、 $A$ はガラスの面積 $(\mathrm{m}) 、 t$ はガラスの板厚 $(\mathrm{mm})$ である。

\section{2 取り付け位置の影響}

上記の様にISO 140-1，3では、試料の両側にできるニッシェの深さ の比が概ね2:1になる位置に試料を設置することを規定している。こ

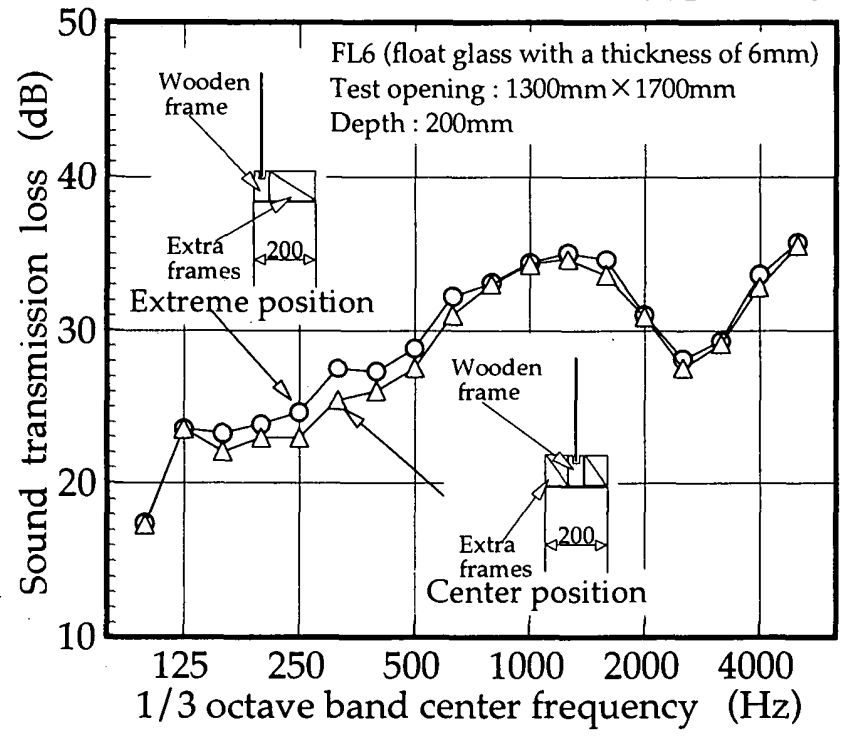

Fig. 3 Influence of the installation of glass pane (niche effect).
れは設置位置の違いによる測定結果の不一致を少なくしようとする ものである。図-3は深さ $200 \mathrm{~mm}$ の試験開口に、6 mm厚のガラスを木枠 を用いて取付け、その取付位置を変えて測定した結果を比較したも ので、中低音域に系統的な差を生じている。この試料の設置位置の 違いによる影響は、ニッシェ効果或いはバッフル効果 ${ }^{4}$.5.6)などと 呼ばれ、試料が中央に位置する場合が透過損失は最も低く、両端に 移動するに従って上界し、端における測定結果が最も高くなる傾向 を指すものである。しかもこの影響は、 $f_{C}$ より低い周波数帯域でし かみられない。さらに深いニッシエがある場合の影響を定性的に確 認するために、図-4に示すような比較実験を試みた。なお、以後の 図中の略語は、FL:フロートガラス、PW網入りガラス、複層ガラス のA:空気層を示し、数値の単位はmmである。

設置位置の条件変更に伴い試料の支持条件か変化しないようにす るために、ニッシェが浅い条件で試料を設置しておき、その両側に $12 \mathrm{~mm}$ 厚の石高ボードによる庇をつけることで、ニッシェの染さを変 化させた。実験は単板ガラス（FL5）と複層ガラス（FL5+A12+ FL5）について実施し、図中に示す記号の無い実線は庇がない場合 の測定結果である。これによるといずれか片方に庇がついた場合は さほど大きな差ではないが、両側についた場合、即ち試料が中央に 位置する場合に $f_{C}$ 以下の周波数の透過損失が最も低下することを示 している。

庇を付けた条件が深いニッシェが生じる場合に直接対応するもの ではないが、同様の傾向は複層ガラスにおいてもみられ、 $f_{C}$ 以下の 周波数における音の放射効率の変化やニッシェ部分のモードの音場 とのカップリングなどによる影響と考えられる。
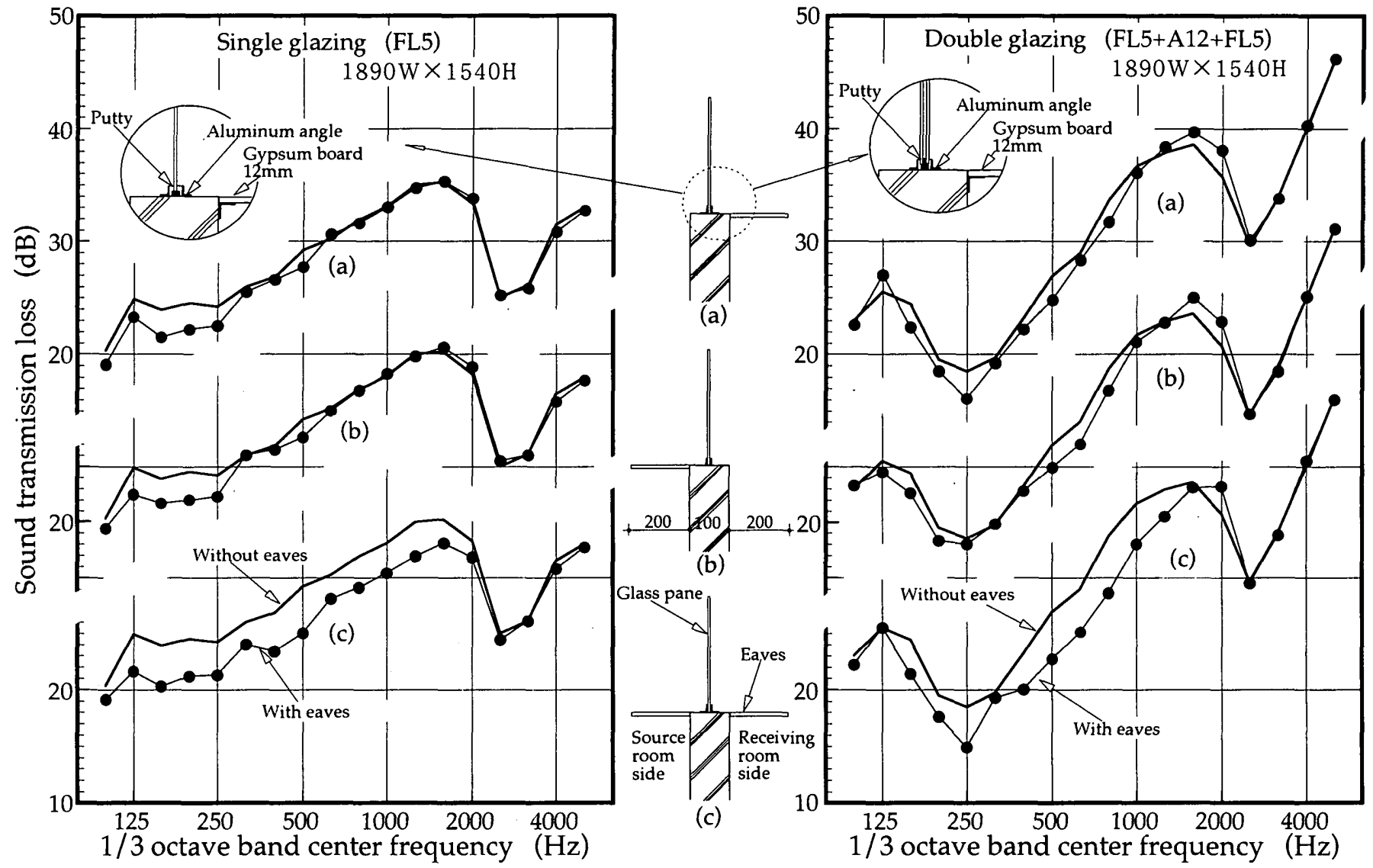

Fig.4 Sound transmission loss versus niches with different depth for single glazing (FL5) and double glazing (FL5+A12+FL5). 


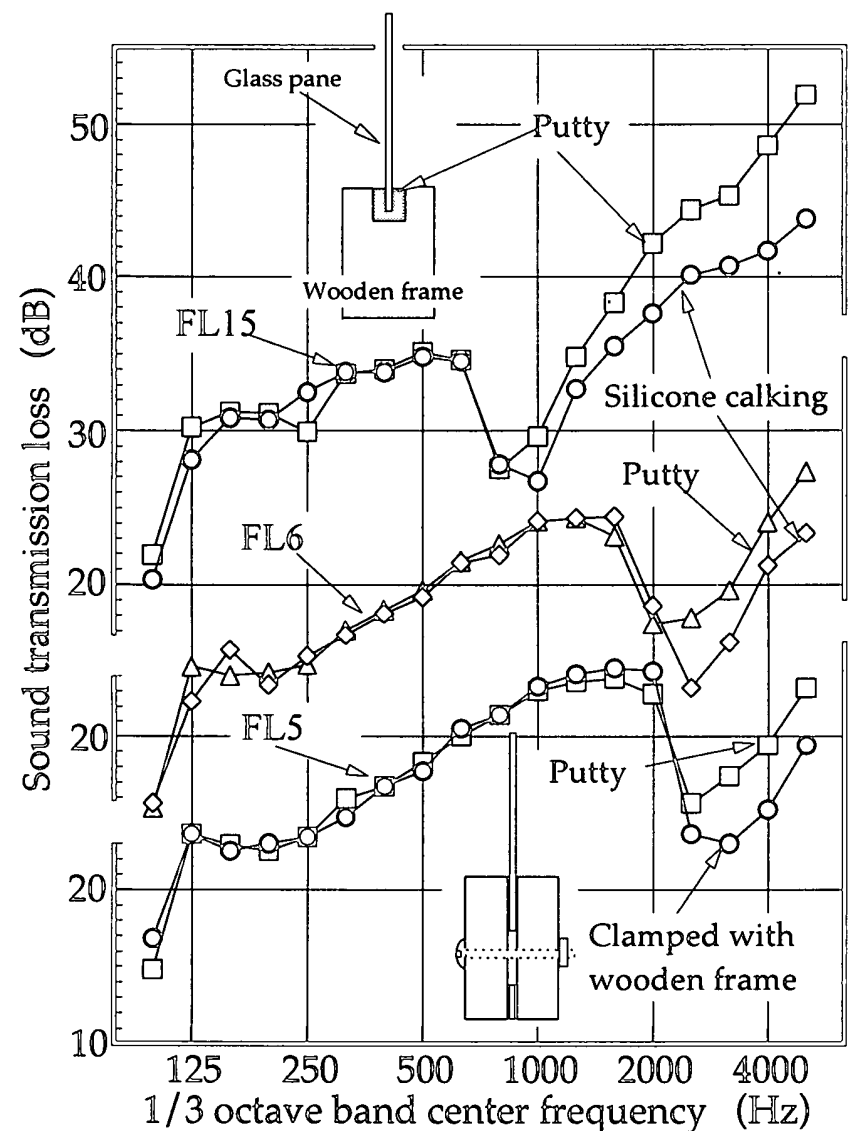

Fig. 5 Sound transmission loss of single glazing for several boundary conditions.

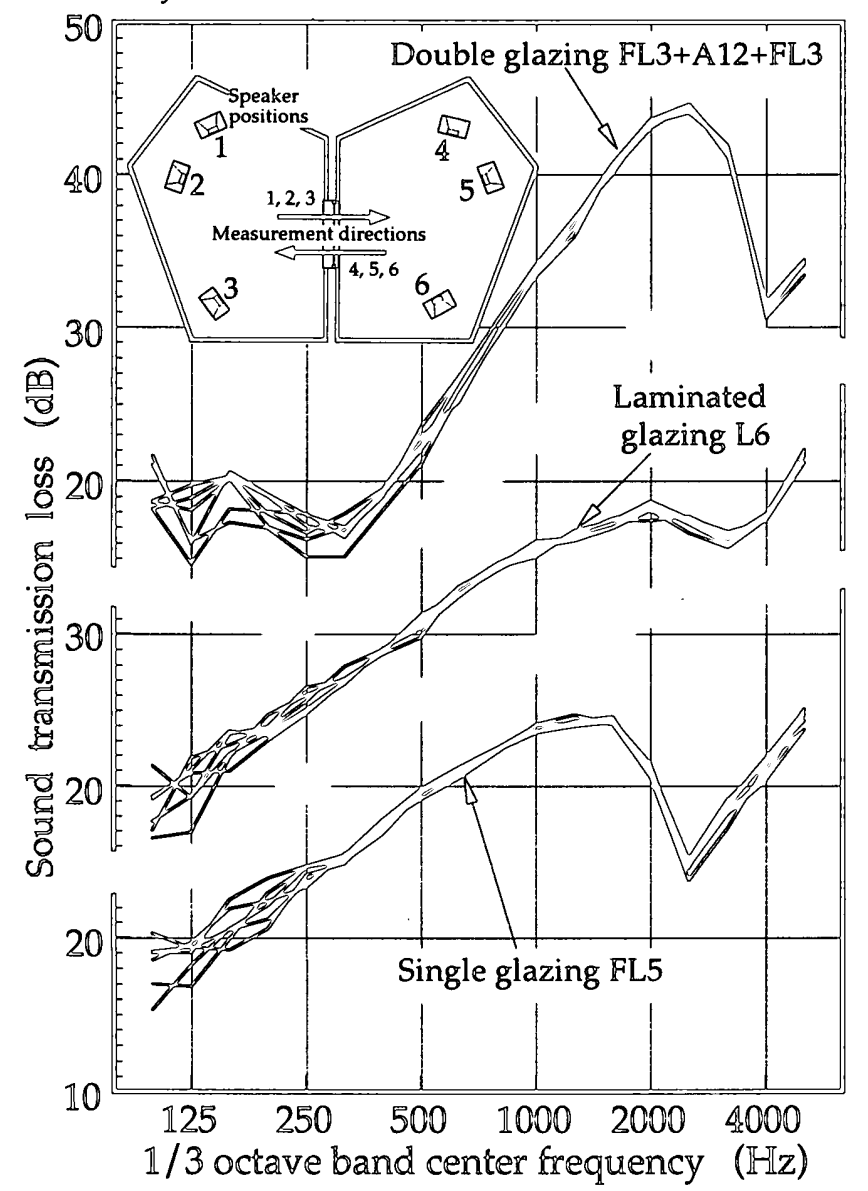

Fig. 6 Measured results of sound transmission loss at different sound source position.

\section{2 . 3 支持部のエネルギーロスの影䌸}

実験室でのガラスの音響透過損失の測定では、試料設置の容易さ やデータの再現性の点から、試料はガラスパテによって設置される のが一般的である。しかし、実際の現場或いはサッシにガラスが取 り付けられる場合は、ガスケットやシリコンコーキングが使われる。 図-5は、単板ガラスの透過損失を試料の固定方法を変えて比較した ものである。いずれの組も固定方法以外の上記の条件は同じにして 測定した。 $f_{C}$ より高い周波效帯域で大きな差を生じている。これは ガラス自身の内部損失が非常に小さいため、試料の周辺支持条件の 影響を大きく受けているものと考えられる。

この結果から、単板ガラスの透過損失を予測するには、実際に測 定用開口部に設置された状態での損失係数を測定し、支持部からの エネルギーロスの影響を定量的に把握する必要があることがわかる。

\section{4 低い周波蘩領域の測定結果の不一致}

ISO 140-3には音源スピーカ及びその設置位置に関する詳細な附属 書（Annex C）が設けてあり、複数の音源位置での繰り返し測定を 行うことにより、低い周波数での拡散性の不足を補い測定宵度を確 保することを規定している。その際、音源は無指向性音源で試験す ることを推奖している。これは吸音力を付加することによる直接音 距離の増加に配虑したものである。

本研究に用いた残響室は、JIS A 1416 「実験室における音郎透過 損失測定方法」に基づいており、ISO 140-1，3の試験室に比へて室容 積が大きく室形も不整形であるが、図-6に示すように複数の音源設 置位置（測定方向反転を含む6か所の音源位置）での測定結果に不 一致を生じている。特に低音域での差異は大きく、測定結果の何ら かの平均化操作が必要なことを示している。この様な不一致は、試 料面積が $10 \mathrm{~m}^{2}$ 程度の場合は比較的少ない7) が、試料が小さくなるほ と測定結果は、試料周辺の拘束状態や音源の局所変化に村して敏感 になるものと考えられる。板ガラスのように供試体自身に明確な共 鳴系のある試料（単板ガラスの低次振動モードや複層ガラスの低音

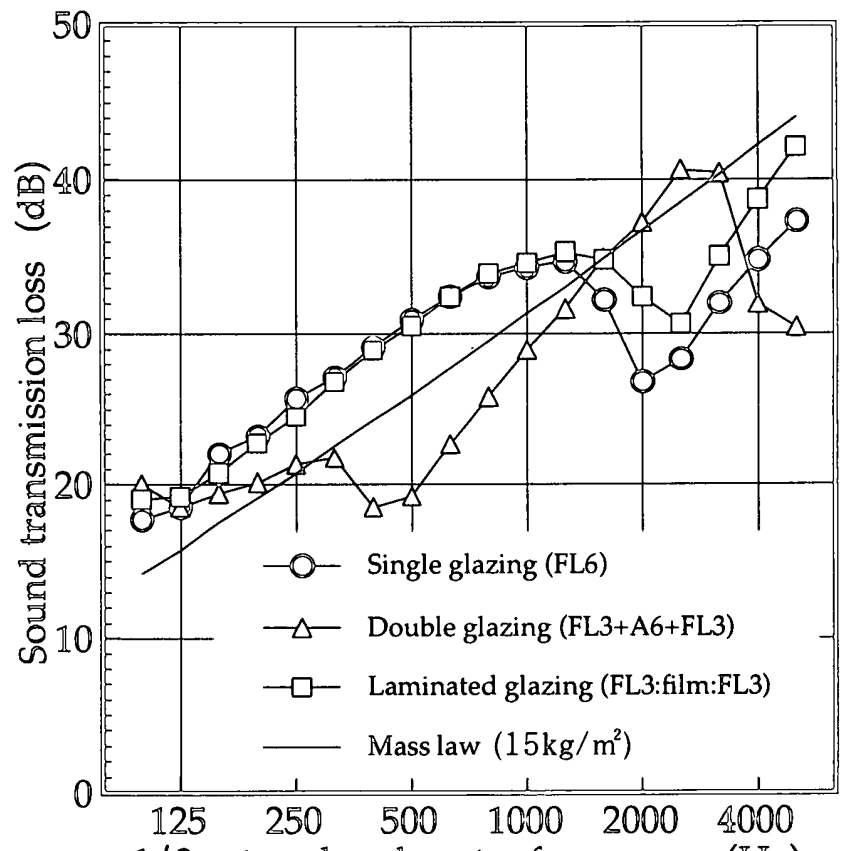

$1 / 3$ octave band center frequency $(\mathrm{Hz})$

Fig. 7 Sound transmission loss performance for different types of glass pane. 
域共鳴透過現象) では、この差異はより大きくなるため、試料相互 の性能の差を比較する際には、ここで述べられた差異の要因とその 定量的な把握が必要になるものと考えられる。

\section{3 . 板ガラスの音響透過損失}

以上の検討結果をふまえた上で、図-1(b)に示したISO方式により、 各種板ガラスの音響透過損失の測定を行った。

\section{1 各種板ガラスの基本特性}

各種の板ガラスの特質を示すために、面密度か等しい単板ガラス、 複層ガラス及び合わせガラスの音響透過損失の測定結果を比較して 図-7に示す。

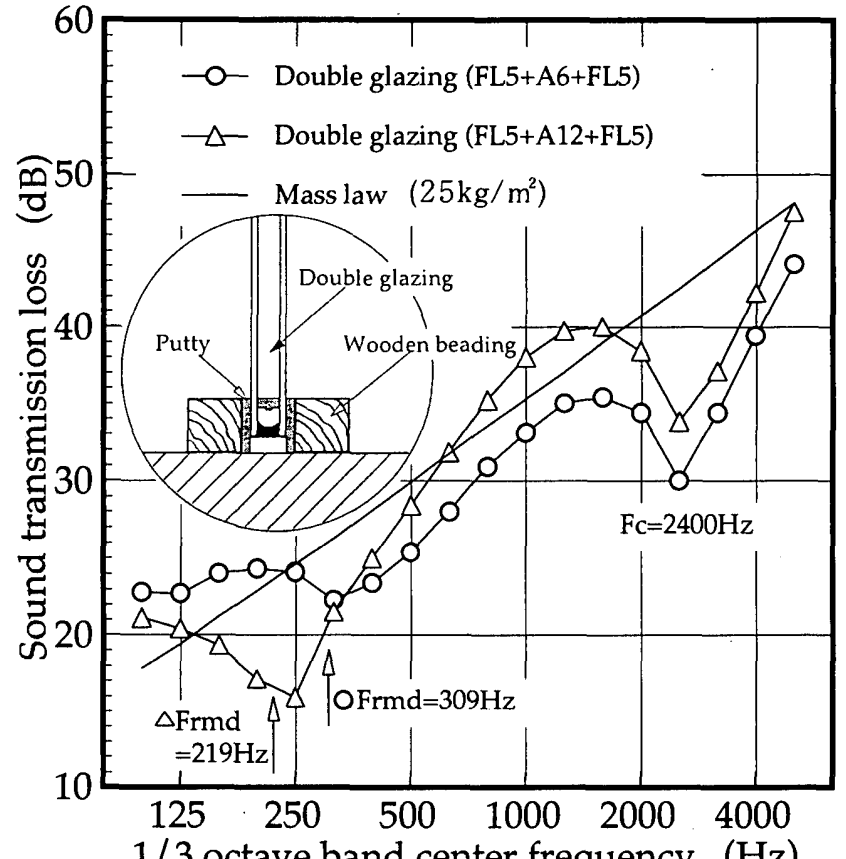

$1 / 3$ octave band center frequency $(\mathrm{Hz})$

Fig. 8 Influence of air space for sound transmission loss performance of double glazing.

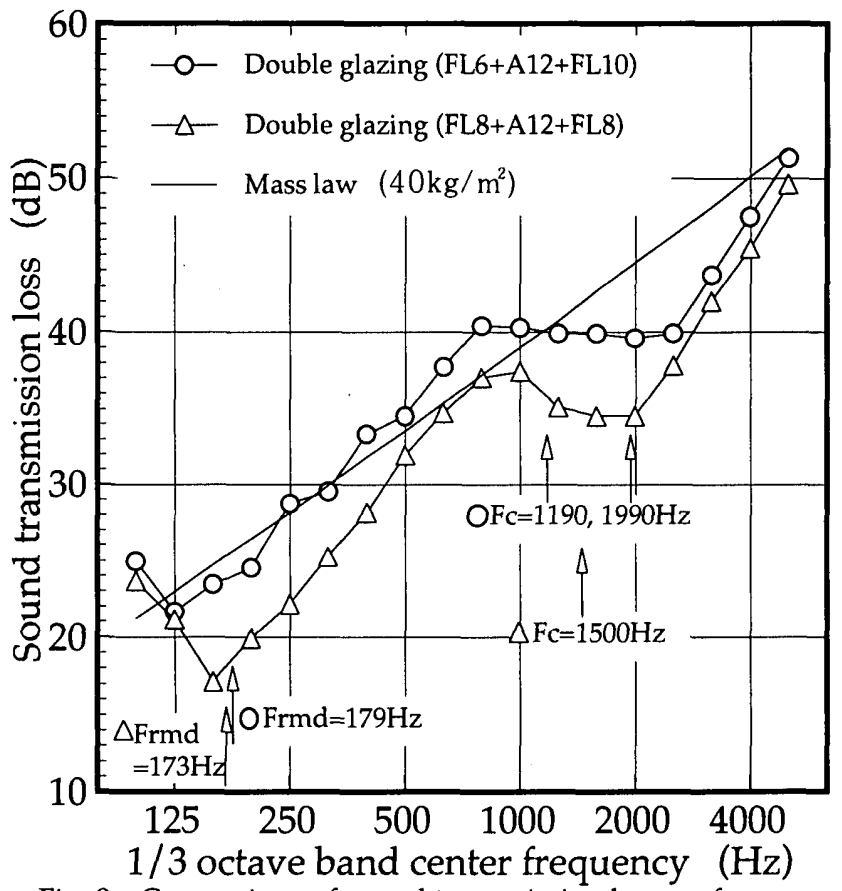

Fig. 9 Comparison of sound transmission loss performance of double glazing constructing glass pane with same thickness and different thickness.
Table-1 Calculated mass-air-mass resonance frequencies for tipical double glazing $(\mathrm{Hz})$

\begin{tabular}{|c|c|c|c|c|c|c|c|c|}
\hline & FL3 & FL4 & FL5 & FL6 & PW6.8 & FL8 & FL10 & FL12 \\
\hline FL3 & $283 / 400$ & & 358 & 346 & 340 & & & \\
\hline FL4 & & & & 316 & 309 & 300 & & \\
\hline FL5 & 253 & & $219 / 310$ & & & 279 & 268 & \\
\hline FL6 & 245 & 224 & 210 & $200 / 283$ & & & & 245 \\
\hline PW6.8 & & & 204 & & & & & \\
\hline FL8 & & 212 & & 187 & & $173 / 245$ & & 224 \\
\hline FL10 & & 205 & & 179 & & 164 & & \\
\hline FL12 & & & & 173 & & 158 & & \\
\hline
\end{tabular}

Interpane spacing ; $6 \mathrm{~mm}$ airspace and $12 \mathrm{~mm}$ airspace (thick character)

複層ガラスの空気層は、空気層内での対流による断熱性能の低下 を防ぐため通常6〜12mm程度とされ、図-7に示すように中低音域に 共鳴透過現象を生じる。このため、単板に比べこの周波数領域での 性能低下に十分配慮しなければならないことがわかる。

共鳴周波数 $f_{r m d}$ は(3)式で計算され、代表的なガラス構成について は表-1のようになる。

$$
f_{r m d}=1200 \sqrt{t_{1}+t_{2}} / \sqrt{t_{1} t_{2} d}
$$

ここに、 $t_{1} 、 t_{2}$ はそれぞれのガラスの厚さ $(\mathrm{mm}) 、 d$ は空気層 の厚さ $(\mathrm{mm})$ である。

また、合わせガラスの遮音性能は、本質的に単板ガラスのそれと 大差ないが、内部損失が大きいので板に生じる屈曲振動か制御され、 $f_{C}$ 以上の周波数領域で単板より高い透過損失となる。単板ガラスの 損失係数 部からのエネルギーロスに強く依存する。内部損失、支持端のロス、 放射ロスなどを含めた総合損失係数 $\eta_{\text {wat }}$ が把握できれば、Cremerの 理論 ${ }^{8)}$ により透過損失を予測することができる。 $f_{C}$ 以上の周波数 範囲については(4)式の簡略式が実測值とよく対応することが確かめ られている9)。

$$
T L=T L_{0}+10 \log _{10}\left(f / f_{C}-1\right)+10 \log _{10} \eta_{\text {tutal }}-2
$$

\section{2 複層ガラスの空気層及びガラス構成}

各種複層ガラスの音響透過損失測定結果を比較して図-8,9に示す。 上記のように複層ガラスの空気層厚さは $6 \sim 12 \mathrm{~mm}$ であり、空気層が $12 \mathrm{~mm}$ の方が互いのガラスの音響的独立性が増すため、中高音域の透 過損失は高くなるが、一方で $f_{r m d}$ が低い周波数に移行するため、ご く低い周波数を対象とした場合には、空気層が6 $\mathrm{mm} の$ 方が有利にな ることがわかる（図-8の矢印参照）。

また、図-9に示すように、同じ厚さのガラスで構成した同厚構成 と、異なる厚さにした異厚構成を比較した場合、 $f_{C}$ 以上の周波数領 域では後者の方が、それぞれのガラスのコインシデンス現象による 低下を補うため落ち込みが少ないことがわかる。なお、厚さの比が 倍以上になると、 $f_{C}$ がオクターブ以上離れ、それぞれのガラスのコ インシデンス現象が別個に生じるため必ずしも有効ではない。

また、中空パネルを面密度の異なる膜とみなした場合の解析から、 共鳴透過時の透過損失は面密度の和が同じならば、面密度の差を大

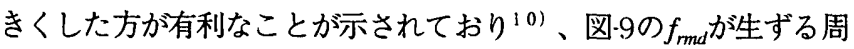
波数領域においても、異厚構成の方が透過損失が高い結果となって いる。

\section{3 合わせガラスの温度特性}

図-7に示したよjに、合わせガラスの内部損失は単板ガラスより 大きいので、 $f_{C}$ の周波数領域での遮音性能が、単板ガラスのそれよ 
りも改善される。しかし、その内部損失は温度依存性が高く、透過 損失の測定結果も温度の影響を強く受けることが予測される。

そこで代表的なPVBフィルムを用いた合わせガラスについて損失 係数の温度特性の測定を行った。測定は合わせガラスL6（FL3：

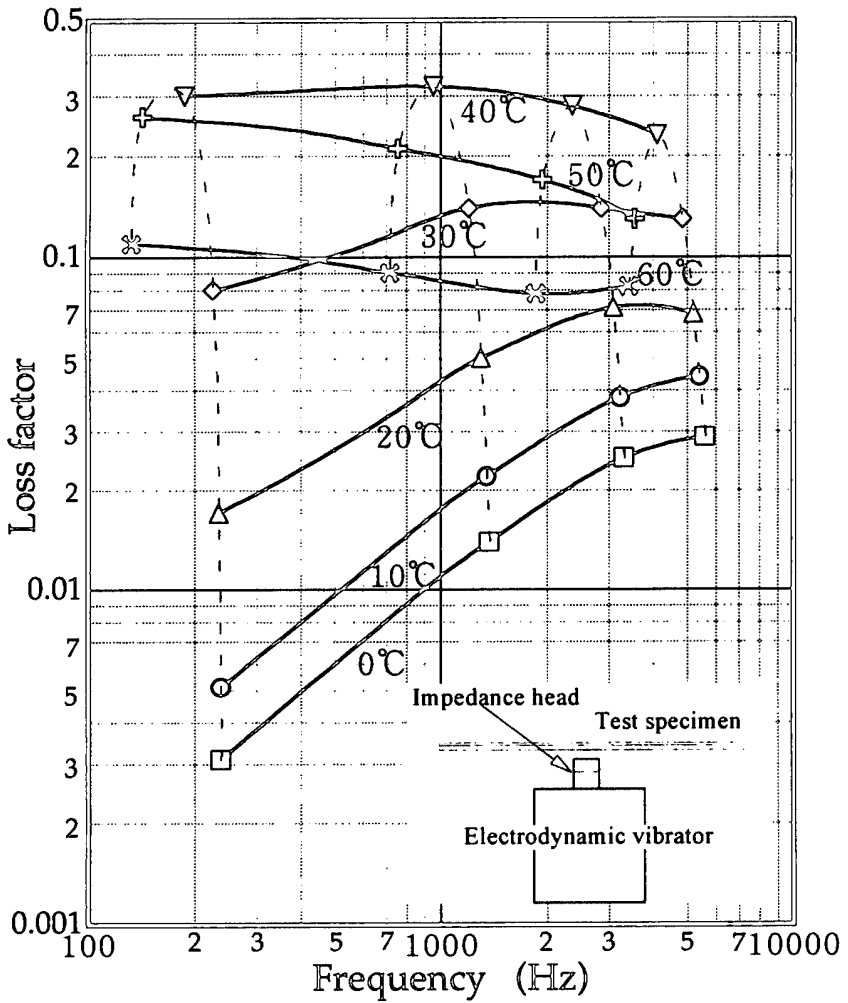

Fig. 10 Temperature characteristics of internal loss factor of laminated glass pane.

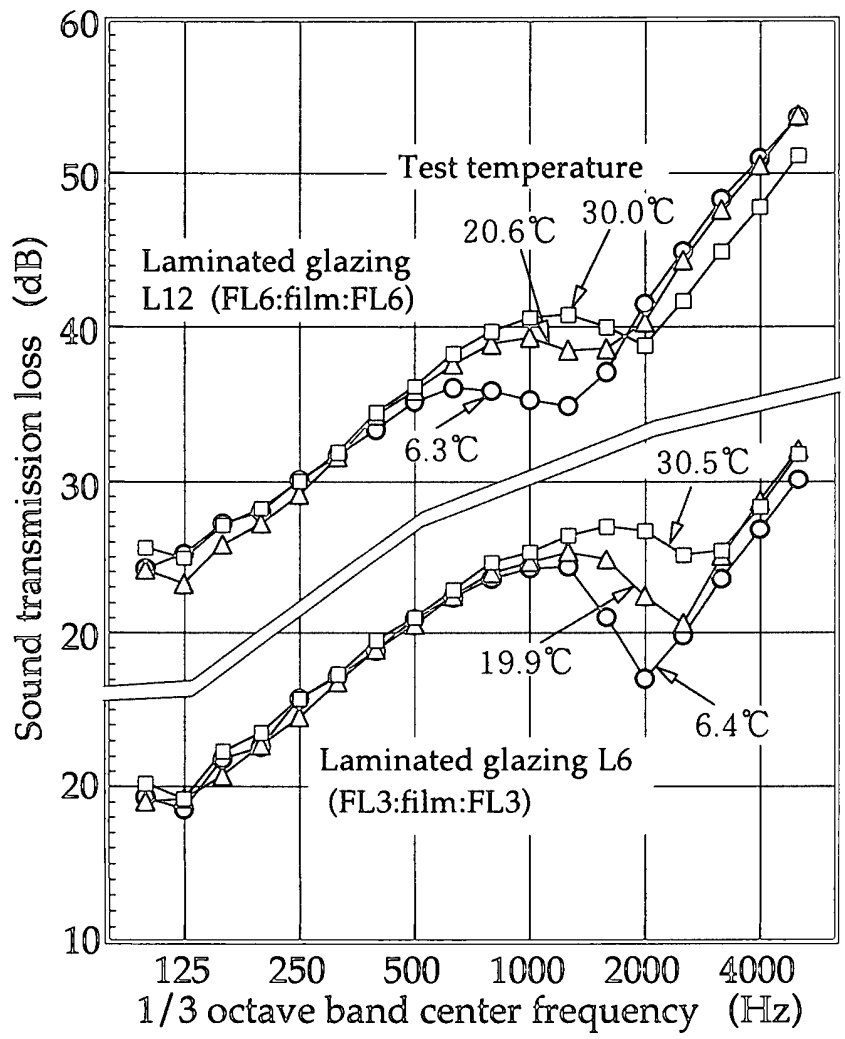

Fig. 11 Measurement results of laminated glazing at various temperature conditions.

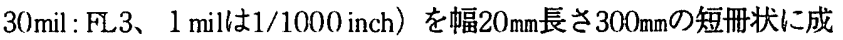
形したものを試料とし、中央加振の機被インピーダンス法によった。 試料及び加振器は恒温槽内に設置し、0〜60年の簛囲で測定温度を 制御した。測定結果を図-10に示す。これをみると、温度の上昇と ともに損失係数は大きくなるが、30４0知を境にまた低下している。 温度が異なる時期に測定したL6とL12についての音嚮透過損失測 定結果を図-11に示す。これをみると、測定温度によって $f_{C}$ 以上の 周波数領域で測定結果が大きく変化することがわかる。厚いがラス 構成ほど $f_{C}$ が低くなるので、内部損失の影響が広い周波数䉇囲にお よんでいる。実際の使用環境では、室内側の温度がここで示した以 上に低くなることは少ないと考えられるが、このような合わせガラ スの温度特性には十分に注意する必要がある。

\section{4.まと虰}

板ガラスの音響透過損失に与える試料の取り付け条件の影嚮につ いて、幾つかの実験結果を基に検討した。板ガラスはその実際の使 用状況に照らし、小さい試料面積で測定されることが多く、試料端 の拘束条件や音場の局所変動の影䇺が、大きい試料で計測される壁 構造などに比べて敏感に反映されてしまう。その要因の一つは試料 を取り付ける開口部の形状や取り付け位置の問題であり、他方は試 料の支持端からのエネルギーロスの問題である。

前者については、異なる条件で測定した結果から、それらの影響 の定性的な傾向を示した。また、後者のエネルギーロスは試料自身 の内部損失に比べて非常に大きく、単板ガラスの $f_{C}$ 以上の周波数領 域での逵過損失に強く影恠していることを示した。

これらの結果をふまえ、各璉の板ガラスの音響透過損失の測定結 果を相互に比較することによって、それぞれのガラス構成の特質を 示した。これらの検討結果や測定結果が、実際の空や空ガラスの遮 音性能の改善に利用されることが期待される。

参考文献

1) ISO 140-1, 3, Measurement of sound insulation in buildings and of building elements -- Part 1 : Requirements for laboratory test facilities with suppressed flanking transmission, Part 3 : Laboratory measurement of airborne sound insulation of building elements.

2) A. Cops, M. Minten and H. Myncke, "Influence of the design of transmission room on the sound transmission loss of glass Intensity versus conventional method", Noise control engineering journal, 28(1987), p121-129.

3 ) E. C. Sewell, "Transmission of reverberant sound through a single - leaf partition surrounded by an infinite rigid baffle", J. Sound Vib. 1970, Vol. 12, p21-32.

4) T. Kihlman and A. C. Nilsson; "The effects of some laboratory designs and mounting conditions on reduction index measurements", J. Sound Vib. 1972, Vol. 24(3), p349-364.

5) R. W. Guy and P. Sauer, "The influence of sills and reveals on sound transmission loss", Applied A. 1984, Vol. 17, p453-476.

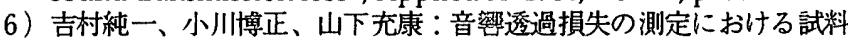

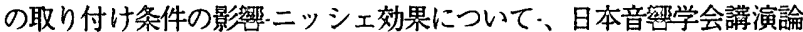
文焦、昭和60年9月、p.641-642.

7）吉村純一、畑中尚、小川博正：実験室における音瑤透過損失の測定 法について、日本音蚃学会建築音響研究会資料、AA93-2.

8 ) L. Cremer, M, Heckl and E. E. Ungar, "Structure-Borne Sound", Springer-Verlag, 1973.

9) J. Yoshimura and J. Kanazawa, "Influence of damping characteristics on the transmission loss of laminated glass," proceedings of Inter-noise 84 (1984) p589.

10）久我新一、田中 洪：異質部材による中空パネルの透過損失につい て、日本音響学会誁演論文焦、1973年10月、p.57.58. 